ISSN: 2085-0344 (Print)

ISSN: 2503-1864 (Online)

Journal homepage: www.ejournal.almaata.ac.id/literasi

Journal Email: literasi_stia@yahoo.com

\title{
Model Sekolah Aman Bencana dalam Upaya Mewujudkan Pendidikan Karakter di MIN 1 Bantul
}

\author{
Nisfi Anisah \\ Program Studi Pendidikan Guru Madrasah Ibtidaiyah UIN Sunan Kalijaga Yogyakarta \\ nisfianisah@gmail.com
}

\begin{abstract}
Abstrak
Anak-anak seringkali menjadi korban kasus cidera saat terjadi kecelakaan maupun bencana alam. Data terakhir dari United Nation International Strategy For Disaster, sebanyak 60 persen anak-anak di dunia ternyata merupakan korban bencana alam. Berbagai ancaman masih mengintai anak seperti bencana alam. Ancaman tersebut diperparah dengan kondisi sekolah yang kurang kondusif, bangunan yang tidak layak, sarana prasarana yang tidak memenuhi standar. Merujuk data 15 tahun terakhir dari BNPB tahun 2017, terdapat 46.648 sekolah yang terdampak bencana. MIN 1 Bantul telah merespon positif model sekolah yang aman bencana dengan dinobatkan sebagai peringkat 3 SEAMEO Japan Education for Sustainable Development (ESD) Award.

Hasil penelitian ini adalah (1) motivasi MIN 1 Bantul membentuk sekolah aman bencana dilatarbelakangi gempa tahun 2006. Selain itu adanya kesadaran akan pentingnya pendidikan keamanan bagi warga madrasah. (2) pelaksanaan program sekolah aman bencana di MIN 1 Bantul berupa sekolah siaga bencana sudah berjalan dengan baik. Program tersebut dilaksanakan dengan memperhatikan kerangka kerja struktural dan non struktural serta mengacu 3 pilar sekolah aman bencana yang meliputi fasilitas sekolah aman, manajemen bencana di sekolah, dan pendidikan pencegahan. (3) Keterkaitan sekolah aman bencana dengan pendidikan karakter adanya keselarasan pelaksanaan sekolah aman bencana dengan pembiasaan yang dilakukan di MIN 1 Bantul.
\end{abstract}

Kata kunci: Sekolah Aman Bencana, Pendidikan Karakter, Nilai-nilai Karakter

\begin{abstract}
Children are often the victims of injuries during accidents and natural disasters. Latest data from United Nation International Strategy For Disaster, as many as 60 percent of children in the world turned out to be victims of natural disasters. Various threats are still lurking children like natural disasters. The threats are exacerbated by the condition of schools that are less conducive, inappropriate buildings, infrastructure that do not meet the standards. Referring to the last 15 years data from BNPB 2017, there are 46,648 schools affected by the disaster. MIN 1 Bantul claimed positively as the safe disaster school model by being ranked 3rd SEAMEO Japan Education for Sustainable Development (ESD) Award.

The result of this research are (1) motivation of establising is due of the eathquake disaster in 2006. It leads to awarness of the importance of safe education in madrasah (2) the implementation of disaster-safe school program in MIN 1 Bantul in the form of disaster preparedness school has been running well. The program is implemented with respect to structural and non-structural frameworks and refers to the three pillars of disaster-safe schools that include safe school
\end{abstract}


facilities, disaster management in schools, and preventive education. (3) The linkage of disastersafe schools with character education of harmony in the implementation of disaster-safe schools with habituation conducted in MIN 1 Bantul.

Keyword: disaster-safe schools, character education, character values

\section{PENDAHULUAN}

Anak-anak seringkali menjadi korban kasus cidera saat terjadi kecelakaan maupun bencana alam. Data terakhir dari United Nation International Strategy For Disaster, sebanyak 60 persen anak-anak di dunia ternyata merupakan korban bencana alam. Hal ini menjadi persoalan serius karena pada 10-20 tahun mendatang dampak bencana akan mempengaruhi fisik serta psikologi anak. Hal senada juga disampaikan oleh Menteri Pemberdayaan Perempuan dan Perlindungan Anak Linda Amalia Sari Gumelar yang mengatakan anak perempuan dan lanjut usia merupakan kelompok paling rentan menjadi korban bencana pada perayaan Hari Anak Perempuan Sedunia dengan tema "Anak Perempuan dan Bencana" yang diselenggarakan oleh Plan Indonesia di Gedung RRI.

Sekolah sebagai sebuah bentuk satuan pendidikan formal seharusnya menjadi tempat yang aman bagi anak. Senada dengan hal tersebut, sekolah sebagai salah satu tempat dimana anak menghabiskan waktu lebih lama. Sehari anak dapat menghabiskan waktu selama \pm 8 jam untuk aktivitas di sekolah. Akan tetapi, data 15 tahun terakhir dari BNPB tahun 2017 yang menyebutkan bahwa, terdapat 46.648 sekolah yang terdampak bencana. Hal ini menunjukan bahwa sekolah belum sepenuhnya menjadi tempat yang aman, bersih, sehat, ramah anak, dan menyenangkan bagi anak dan warga sekolah lainnya. Berbagai ancaman masih mengintai anak baik dari lingkungan sekitar seperti peristiwa alam yang dapat menyebabkan bencana seperti banjir, longsor, gempa bumi, gunung api, kebakaran, dan lain sebagainya. Ancaman tersebut diperparah dengan kondisi sekolah yang kurang kondusif, bangunan yang tidak layak, dan sarana prasarana yang tidak memenuhi standar masih dipertahankan, kepala sekolah, guru, peserta didik, dan orang tua yang tidak memahami hak anak, serta berbagai kerentanan lain yang berisiko mengancam keamanan, keselamatan, dan kenyamanan anak untuk belajar dan tumbuh kembang optimal di sekolah.

Selain itu, pentingnya pendidikan keamanan (Safety Education) bagi sekolah guna membekali peserta didik ketika terjadi bencana secara tiba-tiba. Menurut Dwi, Kepala BPBD Kabupaten Bantul menyatakan bahwa "Edukasi di sekolah tidak cukup hanya dengan memasukkan kurikulum berbasis penanggulangan bencana, tetapi juga harus menciptakan sekolah yang nyaman dan aman bagi siswa dan pengajar ketika terjadi bencana alam, salah satunya gempa bumi. Sebab, bencana alam seperti gempa bumi tidak dapat diprediksi. Tidak menutup kemungkinan gempa bumi bisa saja terjadi pada jam-jam sekolah. Untuk itu, salah satu hal yang terpenting adalah menciptakan sekolah aman dan nyaman". Hal senada juga diungkapkan oleh Disaster Risk Reduction (DRR) Project Manager Plan Indonesia Amin Magatani, "Cara pengurangan risiko bencana anak adalah menerapkan sekolah aman di lokasi yang aman dan tepat. Tak hanya itu saja, pengetahuan dan sikap anak harus banyak didorong untuk penanggulangan risiko bencana".

Kabupaten Bantul merupakan salah satu kawasan rawan bencana alam. Kabupaten Bantul pernah mengalami bencana gempa bumi di tahun 2006 dengan kekuatan 5,9 SR yang memakan korban ribuan orang. Bahkan hingga tahun 2018 ini, Kabupaten Bantul masih sering terjadi gempa dengan kekuatan yang relatif rendah. Kabupaten Bantul, DIY dan wilayah-wilyah berbatasan dengan samudera Hindia dinyatakan rawan gempa bumi. Pasalnya 
berbatasan langsung dengan samudera Hindia yang merupakan wilayah terdekat dengan zona subduksi lempeng Australia dan Eurasia. Selain itu, Bantul merupakan wilayah yang berada pada dominasi struktur geologi Young Merapi Volcanic (Quartenary) bagian tengah dan Volcanic (Miocine dan oligomicine) pada bagian timur. Secara struktural Kabupaten Bantul diapit oleh bukit patahan, yaitu lereng barat Pegunungan Batur Agung (Batur Agung Ranges) pada bagian timur dan bagian Barat berupa bekas laguna. Kejadian gempa bumi 27 Mei 2006 menguatkan predikat Kabupaten Bantul sebagai wilayah yang termasuk dalam kategori wilayah rawan bencana gempa bumi.

Salah satu langkah preventif yang dilakukan Pemerintah guna mengurangi risiko bencana dan melindungi anak saat kegiatan belajar mengajar berlangsung pada satuan pendidikan yaitu dengan adanya program sekolah aman bencana. Sekolah aman bencana merupakan sekolah sebagai tempat yang aman, nyaman, bersih, sehat, hijau, inklusif, dan menyenangkan sebagai bentuk perwujudan dari sekolah ramah anak telah dilakukan berbagai pihak lain (kementerian/lembaga/swasta/mitra pembangunan internasional) yang bekerja sama dengan Kementerian Pendidikan dan Kebudayaan. Sekolah aman bencana mencakup tiga pilar utama yang meliputi fasilitas sekolah aman, manajeman bencana di sekolah, dan pendidikan pencegahan. Dilihat dari ketiga pilar tersebut, penerapan sekolah aman bencana tentunya tidak terlepas dari proses internalisasi nilai-nilai karakter guna membentuk karakter kesiapsiagaan pada warga madrasah/sekolah.

Selain itu, menyadari adanya risiko bencana, penting ditumbuhkan kesadaran dan pembudayaan pengurangan risiko bencana (PRB) di sekolah. Untuk mewujudkan hal tersebut, Pemerintah juga mengeluarkan surat edaran Menteri Pendidikan Nasional No.70a/ MPN/SE/2010 tentang Pengarusutamaan Pengurungan Risiko Bencana di sekolah yang ditujukan kepada gubernur, bupati/walikota seluruh Indonesia.
MIN 1 Bantul merupakan salah satu madrasah yang mengalami kerusakan cukup parah akibat gempa bumi yang pernah mengguncang di Kabupaten Bantul. Hal ini memberikan dampak baik secara psikologis pada peserta didik MIN 1 Bantul. Merujuk data dokumentasi MIN 1 Bantul, sebanyak 42 anak mengalami trauma dan memutuskan untuk keluar dari MIN 1 Bantul.

Langkah preventif dan antisipatif yang dilakukan MIN 1 Bantul yaitu dengan membentuk sekolah aman bencana. Langkah ini bertujuan untuk memberikan informasi serta pendidikan bencana atau pendidikan pengurangan risiko bencana guna menyikapi keadaan alam dan lingkungan sekitar yang rawan bencana alam, sehingga warga MIN 1 Bantul dapat bersikap dan bertindak ketika terjadi bencana alam khususnya gempa bumi.

Program sekolah aman bencana yang ada di MIN 1 Bantul tersebut dilaksanakan pasca bencana gempa terjadi pada masa jabatan Bapak Haris Mufika. Respon positif yang dilakukan MIN 1 Bantul diiringi dengan prestasi yang membanggakan dimana MIN 1 Bantul dinobatkan sebagai peringkat 3 SEAMEO-Japan Education for Sustainable Development (ESD) Award, sebuah penghargaan Internassional Sekolah Siaga Bencana se-Asia Pasifik tahun 2012. Penghargaan tersebut diselenggarakan oleh Organisasi Kementerian Pendidikan Asia Tenggara (Southeast Asian Ministers of Education Organization, SEAMEO) dan Kementerian Pendidikan, Kebudayaan, Olahraga, Sains dan Teknologi Jepang.

Pelaksanaan program sekolah aman bencana memiliki kaitan erat dengan pendidikan karakter. Hal ini karena salah satu tujuan dari pelaksanaan sekolah aman bencana yaitu menanamkan nilai karakter kesiapsiagaan pada warga madrasah/sekolah. Penanaman nilai-nilai karakter pada program sekolah aman bencana dengan cara pembiasaan sepanjang waktu pada warga madrasah/sekolah khususnya pada peserta didik. Berdasarkan kebijakan nasional terdapat 4 pendekatan penanaman nilai-nilai karakter pada satuan pendidikan yang meliputi 
(1) pendekatan terintegrasi dalam semua mata pelajaran; (2) pengembangan budaya satuan pendidikan; (3) pelaksanaan kegiatan ekstrakurikuler, dan (4) pembiasaan perilaku dalam kehidupan. Berdasarkan pemaparan tersebut, untuk itu peneliti mencoba mengkaji lebih dalam tentang program sekolah aman bencana dalam upaya mewujudkan pendidikan karakter di MIN 1 Bantul.

Berangkat dari kenyataan di atas, kajian ini dilandasi adanya kegelisahan terkait pentingnya sekolah yang aman bencana. Oleh karena itu, berdasarkan latar belakang tersebut kajian ini menfokusnya pada model sekolah aman bencana dalam upaya mewujudkan pendidikan karakter. Kajian ini akan menjawab Bagaimana implementasi model sekolah aman bencana dalam upaya mewujudkan pendidikan karakter?. Dengan adanya kajian ini diharapkan dapat memberikan solusi dan gambaran bagi madrasah maupun sekolah terkait model sekolah aman bencana.

\section{METODE PENELITIAN}

Penelitian merupakan penelitian deskriptif kualitatif dengan interpretasi mendalam terhadap temuan-temuan lapangan berdasarkan fakta yang ada mengenai informasi model sekolah aman bencana dalam upaya mewujudkan pendidikan karakter di MIN 1 Bantul. Sumber data dalam penelitian ini meliputi kepala MIN 1 Bantul, guru MIN 1 Bantul serta peserta didik MIN 1 Bantul. Oleh karena itu, penelitian ini menggunakan teknik pengambilan sampel bertujuan (purposive sampling). Teknik yang digunakan untuk mengumpulkan data berupa wawancara, observasi dan dokumentasi.

Teknik analisis data dilakukan dengan menggunakan model analisis Miles dan Huberman yang terdiri dari tiga komponen pokok yaitu reduksi data, sajian data, dan penarikan kesimpulan. Tiga komponen analisis tersebut saling berkaitan dan berinteraksi. Untuk mengecek keabsahan data, penelitian ini menggunakan triangulasi sumber dan triangulasi teknik.

\section{HASIL DAN PEMBAHASAN Motivasi MIN 1 Bantul Membentuk Sekolah Aman Bencana}

Pendidikan berasal dari kata "education" yang diterjemahkan dalam bahasa Indonesia dengan "pendidikan. Sedangkan secara umum keamanan diartikan sebagai keadaan terlindungi, tidak terluka, karena bahaya, aman, tidak melibatkan risiko. Menurut Obioma bahwa seluruh keamanan yang diarahkan pada anak adalah agar anak tersebut tetap hidup dan aman, sebagai berikut:

"All safety directed to the child is to keep him/her alive and secured. Examples, we ensure for the child: safety from harm, safety from abuse e.g. rape, safety from disease, safety from malnutrition, safety from hazardous activities, like hawking, street trading, bus conducting, street begging etc, safety from substance abuse, and safety from road accidents".

Pendidikan keamanan merupakan pendidikan rangka mencegah, menghindari, atau menanggulangi terjadinya kecelakaan, sehingga tercipta kehidupan masyarakat yang selamat, bahagia dan sejahtera. Selain itu, pendidikan keamanan dapat diartikan sebagai suatu upaya pendidikan tentang penanggulangan, pencegahan, dan penghindaran dari terjadinya kecelakaan, yang bertujuan agar memperoleh keselamatan bagi manusia dan harta bendanya.

Sejalan dengan hal tersebut, pendidikan keamanan merupakan wujud dari perlindungan anak sesuai dengan Undang-Undang Nomor 23 Tahun 2002, yaitu segala kegiatan yanguntuk menjamin dan melindungi anak dan hak-haknya agar dapat hidup, tumbuh, berkembang, dan berpartisipasi secara optimal sesuai dengan harkat dan martabat kemanusiaan, serta mendapat perlindungan dari kekerasan dan diskriminasi.

Obioma sebagai Executive Secretary NERDC, Abuja menyatakan bahwa terdapat dua pendekatan yang dapat dilakukan dalam pendidikan keamanan di sekolah yaitu: 


\section{Curricular Approach}

Here the concept, themes and messages of Child Safety Education are structured and infused into carrier subjects (e.g. English Studies, Social Studies, Cultural and Creative Arts, Physical and Health Education) are taught in schools. It cannot be a 'Stand alone subject because the Curriculum is alreadyoverloaded.

2. Co-curricular Approach

This will involve the Formation of Safety Clubs in schools. Peer educators would be needed to educate their peers and the community members.

Pendidikan keamanan yang diterapkan di madrasah/sekolah tentunya memiliki beberapa tujuan. Mengacu dari UNHCR, tujuan dari pendidikan keamanan diantaranya:

1. to save lives and ensure the effective protection of girls and boys of concern to UNHCR in learning environments.

2. to ensure that learning environments provide quality education.

3. to empower girls by ending gender discrimination in school environments.

4. to increase school attendance, especially at the secondary level.

5. to help the search for durable solutions by promoting a culture of peace and dialogue.

6. to provide children with the skills to achieve self-reliance.

7. to prevent all forms of sexual and genderbased violence, guard children against sexually transmitted diseases-including HIV and AIDS - and reduce teenage pregnancies and their associated risks.

Dengan demikian, pendidikan aman memiliki tujuan memberikan rasa aman dan terlindungi pada anak akan resiko bahaya yang terjadi di rumah, di sekolah, di jalan dan tempat lainnya. Wujud program pendidikan keamanan khususnya dilembaga pendidikan di Indonesia yaitu adanya sekolah aman

Sekolah sebagai suatu bentuk satuan pendidikan formal yang memberikan fasilitas keamanan dan kenyamanan bagi seluruh warga belajar guna melindungi dari cidera bahaya dan bencana. Sekolah juga sebagai tempat berlangsungnya interaksi guru dan peserta didik untuk melaksanakan kegiatan belajar mengajar yang dilaksanakan dalam setiap hari. Program sekolah aman bencana merupakan salah satu program dari UNICEF. Program sekolah aman bencana ini merupakan kelanjutan dari program-program terdahulu yang meliputi program sekolah sehat dan sekolah adiwiyata. Program sekolah aman bencana memiliki tujuan memberikan pendidikan kepada seluruh warga sekolah/madrasah baik peserta didik, pendidik, tenaga pendidik, kepala madrasah, dan orang tua guna membekali pengetahuan dan keterampilan (skill).

MIN 1 Bantul yang dahulunya bernama MIN Jejeran. MIN 1 Bantul sebagai salah satu madrasah yang terletak di Kecamatan Pleret Kabupaten Bantul. Kabupaten Bantul sebagai salah satu wilayah yang rawan terjadi gempa bumi. Tahun 2006 lalu, gempa sebesar 5,9 SR mengguncang wilayah Kabupaten Bantul. Gempa tersebut merusak sebagai besar sarana prasarana dan infrastruktur MIN 1 Bantul. Gempa bumi tersebut memberikan dampak baik secara psikologis maupun fisik. Secara psikologis memberikan dampak rasa trauma, takut, panik pada warga MIN 1 Bantul. Sedangkan secara fisik bencana gempa tersebut mengakibatkan cidera pada fisik. Mengacu data dokumentasi MIN 1 Bantul, sebanyak 42 anak mengalami trauma sehingga keluar dari MIN 1 Bantul.

Langkah yang dilakukan MIN 1 Bantul guna memberikan serta informasi tentang pendidikan kesiapsiagaan warga MIN 1 Bantul yaitu dengan membentuk sekolah yang aman bencana yang berupa sekolah siaga bencana. Motivasi dan alasan MIN 1 Bantul membentuk sekolah aman bencana berupa sekolah siaga bencana dilatar belakangi peristiwa bencana gempa bumi tahun 2006 lalu yang pernah melanda wilayah Kabupaten Bantul. Selanjutnya pihak MIN 1 Bantul menyadari pentingnya pendidikan keamanan dan pendidikan kesiapsiagaan yang harus ditumbuhkan pada warga MIN 1 Bantul 
mengingat bencana alam khususnya gempa terjadi secara tiba-tiba. Pendidikan tersebut perlu diajarkan dan dibekalkan sejak dini pada warga MIN 1 Bantul agar bersikap lebih tenang ketika bencana terjadi.

\section{Implementasi Sekolah Aman Bencana di MIN 1 Bantul}

Sekolah aman dibagi menjadi tiga definisi, yaitu definisi umum, definisi khusus dan definisi terkait pengurangan risiko bencana. Berikut rinciannya:

1. Pengertian umum: sekolah aman adalah sekolah yang mengakui dan melindungi hak-hak anak dengan menyediakan suasana dan lingkungan yang menjamin proses pembelajaran, kesehatan, keselamatan, dan keamanan siswanya terjamin setiap saat.

2. Pengertian khusus: sekolah aman adalah sekolah yang menerapkan standar sarana dan prasarana yang mampu melindungi warga sekolah dan lingkungan di sekitarnya dari bahaya bencana.

3. Pengertian terkait PRB: sekolah aman adalah komunitas pembelajar yang berkomitmen akan budaya aman dan sehat, sadar akan risiko, memiliki rencana yang matang dan mapan sebelum, saat, dan sesudah bencana, dan selalu siap untuk merespons pada saat darurat dan bencana.

Sekolah aman memiliki sasaran dalam menghadapi bahaya yang sudah diperkirakan, baik yang alami ataupun buatan manusia, adalah untuk:

1. Melindungi peserta didik, guru dan tenaga kependidikan lainnya dari risiko kematian dan cedera di sekolah.

2. Merencanakan kesinambungan pendidikan dalam menghadapi bahaya yang sudah diperkirakan.

3. Memperkuat ketangguhan warga komunitas terhadap bencana melalui pendidikan.

4. Melindungi investasi di sektor pendidikan.

Dari beberapa pengertian di atas dapat ditarik kesimpulan bahwasannya sekolah aman dapat diartikan sekolah yang didesain guna menciptakan rasa aman dan memberikan perlindungan bagi seluruh warga madrasah/ sekolah.

Sekolah aman bencana dilaksanakan mengacu pada 3 pilar utama, yaitu: (1) fasilitas sekolah aman, (2) manajemen bencana di sekolah, dan (3) pendidikan pencegahan dan pengurangan risiko bencana. Pilar pertama mencakup pemilihan lokasi madrasah/sekolah, standar bangunan, standar kinerja, desain yang aman terhadap bencana, pelatihan bagi pembuat bangunan, pengawasan konstruksi, kontrol terhadap kualitas, pemodelan ulang atau renovasi, dan perkuatan.

Pilar kedua mencakup pengkajian dan perencanaan perlindungan fisik dan lingkungan, keterampilan dan perlengkapan respon, adanya perwakilan komite manajemen bencana di sekolah, adanya rencana keberlanjutan pendidikan, dan adanya prosedur tetap (PROTAP atau SOP).

Pilar yang ketiga pendidikan pencegahan dan pengurangan risiko bencana mencakup $\mathrm{PRB}$ yang terintegrasi ke dalam kurikulum formal, adanya pelatihan guru \& pengembangan staff, dan adanya ekstrakurikuler dan pendidikan informal berbasis-masyarakat. Ketiga pilar ini mengacu pada modul sekolah aman dan antara satu dengan yang lain memiliki keterkaitan antara satu dengan yang lainnya guna mewujudkan madrasah/sekolah yang aman.

Model sekolah aman bencana di MIN 1 Bantul berupa sekolah siaga bencana. Program sekolah siaga bencana sebagai upaya kesiapsiagaan madrasah/sekolah guna membangun kesadaran warga madrasah terkait pentingnya kesiapsiagaan madrasah/sekolah. Program tersebut merupakan respon terhadap bencana gempa bumi yang terjadi tahun 2006 silam. Sejarah mencatat bahwa MIN 1 Bantul pada tahun 2006 lalu sejak terjadi peristiwa gempa terjadi kerusakan yang cukup berat dimana gedung MIN 1 Bantul rata dengan tanah. Melalui bantuan dari PLAN dan Kemenag, gedung-gedung MIN 1 Bantul dibangun kembali dengan disetting untuk tahan gempa. 
Mengetahui pentingnya keselamatan dan keamanan, kepala MIN Bapak Haris Mufika membuat program terkait sekolah aman bencana yaitu sekolah siaga bencana. Merujuk dokumentasi MIN 1 Bantul, program sekolah siaga bencana pernah meraih juara 3 tingkat internasional sebagai sekolah siaga bencana dalam SMEAMEO Award tahun 2012.

MIN 1 Bantul fokus pada programprogram yang dikembangkan dan secara eksplisit tertulis dalam visi sekolah. Visi tersebut sudah mencermin salah satu program andalan MIN 1 Bantul yang terkaitan dengan model sekolah aman bencana yaitu sekolah siaga bencana. Visi tersebut kemudian dikembangkan melalui misi madrasah yang memiliki kaitan dengan model sekolah aman bencana yang terdapat pada poin 8 yaitu "Meningkatkan kesiapsiagaan warga madrasah menghadapi bencana". Sedangkan pada tujuan MIN 1 Bantul sesuai pada poin 9 yaitu "Meningkatkan kesiapsiagaan warga madrasah menghadapi bencana" dan poin 14 "Mengkondisikan kesiapan warga madrasah dalam menghadapi bencana". Berdasarkan visi, misi dan tujuan MIN 1 Bantul tersebut tentunya model sekolah aman diimplementasikan melalui budaya madrasah dan terintegrasi dalam pembelajaran.

Kesuksesan pelaksanaan sekolah aman di MIN 1 Bantul tentunya melibatkan banyak pihak. Madrasah mempunyai peran penting, dimana madrasah yang memfasilitasi segala kegiatan pembelajaran serta fasilitas yang mendukung guna tercipta madrasah yang aman. Kepala madrasah berperan sebagai orang yang mengambil segala keputusan dalam setiap kebijakan terkait kegiatan sekolah aman. Guru sebagai fasilitator dalam pembelajaran memiliki peran untuk terus menginovasi kegiatan pembelajaran serta membimbing peserta didik dalam memahami apa itu bencana, apa saja akibat yang ditimbulkan dari bencana tersebut, dan tindakan apa yang harus dilakukan untuk menghadapi bencana tersebut. Selain itu, tidak lepas peran orang tua yang mendukung segi pendanaan dan lainnya agar terlaksananya program sekolah aman di MIN 1 Bantul. Peran dari organisasi PLAN, LINGKAR, BPBD, PMI, dan FPRB. Organisasi tersebut yang merangkul MIN 1 Bantul untuk menerapkan program sekolah aman.

Selain itu, terdapat unsur/aspek lain yang mendukung sekolah aman yakni aspek struktural dan non struktural. Aspek struktural berupa konstruksi fisik sekolah/madrasah untuk mengurangi risiko bencana. Sedangkan aspek non struktural berupa upaya mengurangi risiko bencana yang tidak melibatkan konstruksi fisik. Termasuk disini bisa berupa upaya pembuatan kebijakan seperti pembuatan suatu peraturan, legislasi, kampanye penyadaran masyarakat, membangun sikap dan tindakan kesiapsiagaan kepada seluruh warga sekolah/madrasah dalam menghadapi bencana, yaitu penyiapan sumber daya manusia melalui pendidikan dan pelatihan.

\section{Keterkaitan Pelaksanaan Sekolah Aman Bencana dalam Mewujudkan Pendidikan Karakter}

Sekolah sebagai salah satu wadah strategis dan efektif guna mewujudkan pendiidkan karakter. Pendidikan karakter di satuan pendidikan tidak hanya sebatas memberikan pemahaman, tetapi juga mengajak peserta didik untuk mencintai perilaku kebaikan dan menjadikan hal tersebut sebagai kebiasaan. Sebagai wadah yang strategis, sekolah sebagai satuan pendidikan dapat melakukan pembinaan dan pengembangan karakter dengan menggunakan pendekatan: (1) pendekatan terintegrasi dalam semua mata pelajaran; (2) pengembangan budaya satuan pendidikan; (3)

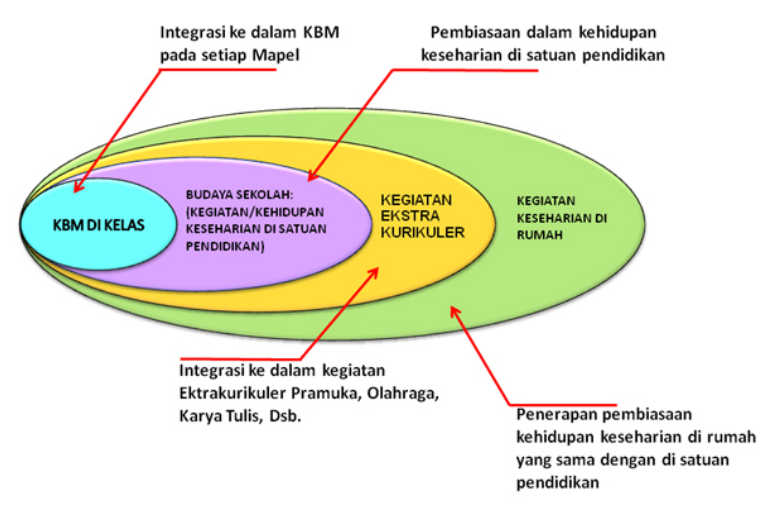

Gambar 1. Desain Pendidikan Karakter 
pelaksanaan kegiatan ekstrakurikuler, dan (4) pembiasaan perilaku dalam kehidupan sekolah. Berikut bagan konteks mikro pendidikan karakter berdasarkan kebijakan nasional pendidikan karakter.

Implementasi pendidikan karakter di sekolah dikembangkan melalui pengalaman belajar dan proses pembelajaran yang bermuara pada pembentukan karakter dalam diri peserta didik. Pendidikan karakter dalam kegiatan belajar mengajar di kelas, dilaksanakan menggunakan pendekatan terintegarsi dalam semua mata pelajaran. Selain itu, pendidikan karakter juga dikembangkan melalui kegiatan peserta didik secara ekstrakurikuler. Kegiatan pembinaan kesiswaan juga merupakan wadah yang potensial untuk pendidikan karakter. Pendidikan karakter di sekolah dapat juga dapat melalui pengelolaan sekolah. ${ }^{1}$

Pendidikan karakter bertujuan membentuk kepribadian anak. Agar terlaksana penanaman pendidikan karakter, perlu adanya programprogram sekolah yang melibatkan kerja sama antara guru dan kepala sekolah untuk mengimplementasikannya dalam kegiatan belajar mengajar. Pendidikan karakter ini berkaitan erat dengan "habit" atau kebiasaan yang dilakukan. Pendidikan karakter diharapkan dapat menyentuh ketiga domain (kognitif, afektif, dan psikomotorik) sehingga peserta didik tidak sekadar tahu akan tetapi juga mau dan mampu melaksanakan apa yang mereka ketahui kebenarannya. Pelaksanaan pendidikan memiliki tujuan penting untuk menanamkan nilai-nilai yang baik dan positif pada peserta didik agar menjadi sebuah karakter. Pelaksanaan pendidikan karakter di lembaga pendidikan khususnya madrasah/sekolah dapat dilaksanakan melalui beberapa pendekatan. Terdapat empat pendekatan yaitu kegiatan belajar mengajar di kelas, adanya budaya madrasah/sekolah, adanya ekstrakurikuler dan kegiatan keseharian di rumah.

${ }^{1}$ Endah Sulistyowati, Implementasi Kurikulum Pendidikan Karakter, (Yogyakarta: Citra Aji Prama, 2012), hlm.11-12.
MIN 1 Bantul sebagai salah satu madrasah unggulan memiliki berbagai program madrasah yang tertuang dalam visi dan misi madrasah. Program tersebut meliputi sekolah sehat, sekolah adiwiyata, sekolah ramah anak, sekolah aman dan sekolah siaga bencana. Pelaksanaan pendidikan karakter melalui sekolah aman di MIN 1 Bantul ini dilakukan melalui empat pendekatan diantaranya: (1) pendekatan terintegrasi dalam semua mata pelajaran; (2) pengembangan budaya satuan pendidikan; (3) pelaksanaan kegiatan ekstrakurikuler, dan (4) pembiasaan perilaku dalam kehidupan madrasah. ${ }^{2}$ Empat pendekatan pendidikan karakter tersebut untuk lebih jelasnya sebagai berikut:

\section{Terintegrasi dalam semua mata pelajaran}

Pendekatan pendidikan karakter salah satunya melalui integrasi mata pelajaran. MIN 1 Bantul sudah mengintegrasikan pendidikan karakter dari program sekolah aman dalam semua mata pelajaran ataupun kurikulum, dan tidak berdiri sendiri. Bahkan pendidikan karakter dari sekolah aman sudah melekat pada visi, misi dan tujuan MIN 1 Bantul. Untuk itu, guru dalam kegiatan belajar mengajar dituntut untuk memasukkan nilai karakter dari sekolah aman dalam silabus dan RPP maupun pelaksanaanya.

\section{Pengembangan budaya di MIN 1 Bantul}

MIN 1 Bantul Yogyakarta adalah mempunyai budaya madrasah (school culture) yang kokoh, dan tetap eksis. Budaya di MIN 1 Bantul diiantaranya yaitu salam dan senyum, salaman pagi, upacara bendera, tadarus dan dhuha, seragam madrasah, sholat berjamaah, jum'at bersih, senam ceria, PHBI dan PHBN, doa bersama, sima'an qur'an, madrasah sehat, kerja keras, cerdas, iklas, infaq jum'at, kantin kejujuran, wisuda siswa, ramadhan ceria, keteladanan, kotak temuan, ekstrakurikuler, peduli sesama, pendampingan, peduli lingkungan, dan siaga bencana.

\footnotetext{
${ }^{2}$ Sri Narwanti, Pendidikan Karakter, ... hlm.42.
} 
Penanaman budaya program sekolah aman di MIN 1 Bantul berdasarkan hasil observasi peneliti diantaranya seperti memarkirkan sepeda dan menata sepatu untuk selalu menghadap keluar, membuang sampah pada tempatnya. Guru dan karyawan pun juga memarkir kendaraan bermotornya dengan menghadap keluar. Hal ini terbukti bahwasannya dengan kebiasaan tersebut sudah menjadikan budaya di sekolah ini. Budaya untuk memarkirkan kendaraan untuk menghadap keluar juga dilakukan oleh orang tua peserta didik MIN 1 Bantul saat menjemput anak-anak pulang sekolah. Para tamu yang datang ke MIN 1 Bantul juga mulai mengikuti budaya tesebut jika bertamu ke MIN 1 Bantul. Hal ini dikarenakan pemasangan rambu "Parkir Menghadap Keluar" yang memiliki tujuan untuk memarkirkan kendaraan menghadap keluar disemua area parkir, sehingga para tamu mengikuti peraturan tersebut. Budaya siaga menjadikan ciri khas dari madrasah ini dibandingkan dengan madrasahmadrasah lain, sehingga pengembangan budaya di MIN 1 Bantul ini sesuai dengan tujuan dari sekolah aman sehingga program tersebut dapat berjalan dengan pencapaian yang sangat baik.

\section{Pelaksanaan ekstrakurikuler Pramuka}

Kegiatan ekstrakurikuler sebagai kegiatan diluar mata pelajaran yang membantu peserta didik untuk mengembangkan bakat dan minatnya. Kegiatan esktrakurikuler di MIN 1 Bantul yang mendukung penanaman karakter sekolah aman yaitu ekstrakurikuler pramuka. Ekstrakurikuler pramuka dapat membentuk karakter peserta didik melalui keteladanan serta pembiasaan yang dilakukan dalam kegiatan pramuka. Kegiatan Pramuka mampu melatih peserta didik untuk disiplin, bertanggung jawab, tolong menolong, dan nilai karakter lainnya yang memiliki kaitan erat dengan nilai karakter pada sekolah aman.

\section{Pembiasaan perilaku dalam kehidupan madrasah/sekolah}

Pembiasaan merupakan salah satu pendekatan yang dilakukan untuk menanamkan nilai karakter pada peserta didik. Pembiasaan ini bertujuan untuk mengenalkan dan mengajak peserta didik agar terbiasa berperilaku atau bertindak sesuai dengan aturan yang ada. Pembiasaan dalam rangka menanamkan nilai karakter yang berkaitan dengan sekolah aman di MIN 1 Bantul mencakup pembiasaaan memarkir sepeda dan sepeda motor dengan menghadapkan sepeda dan sepeda motor ke arah luar. Hal ini bertujuan untuk memudahkan warga madrasah baik guru maupun peserta didik untuk menyelamatkan diri ketika bencana.

Selanjutnya peserta didik MIN 1 Bantul dibiasakan untuk meletakkan sepatu dirak yang disediakan pihak madrasah dengan cara menghadapkan sepatu keluar. Selanjutnya penanaman pendidikan karakter yang dilakukan di MIN 1 Bantul pada peserta didik tentunya memiliki tujuan. Salah satu tujuannya guna membentuk peserta didik yang memiliki karakter baik yang diaktualisasikan melalui sikap dan perilaku di madrasah, di rumah maupun di lingkungan masyarakat. Proses aktualisasi nilai-nilai karakter tersebut merupakan proses yang keberlanjutan guna menerapkan atau mengamalkan nilai-nilai karakter dalam suatu perilaku. Nilai-nilai yang telah berhasil diinternalisasikan kemudian diterapkan dalam kehidupan sehari-hari.

Berikut nilai karakter yang diaktualisasikan dalam sekolah aman bencana di MIN 1 Bantul yaitu:

\section{Disiplin}

Sikap disiplin yang ditanamkan pada peserta didik MIN 1 Bantul dibangun dan ditanamkan melalui pembiasaan yang dilakukan pihak MIN 1 Bantul. Misalnya adanya pembiasaan memarkirkan sepeda pada peserta didik mampun membangun nilai karakter disiplin pada anak. Hal ini dapat terlihat ketika peserta didik yang mengendari sepeda ke MIN 1 Bantul dengan sigap lalu memarkirkan sepedanya dengan menghadap keluar tanpa diingatkan guru atau pihak madrasah. ${ }^{3}$

${ }^{3}$ Hasil observasi pada Jumat, 6 Februari 2018 pukul 


\section{Tanggung jawab}

Sikap tanggung jawab ditanamkan pada peserta didik MIN 1 Bantul melalui pembiasaan. Misalnya adanya pembiasaan untuk menata meja kursi kelas saat akan pulang. Penataan meja dan kursi dilakukan sesuai jadwal piket kelas yang telah dibuat. Hal ini bertujuan selain melatih nilai tanggung jawab juga melatih kerja sama antar peserta didik.

\section{Saling percaya}

Sikap saling percaya ditanamkan melalui kegiatan simulasi bencana alam. Simulasi yang dilakukan meliputi 2 jenis simulasi yaitu simulasi mendadak dan simulasi terencana. Kegiatan simulasi dilakukan biasanya saat peserta didik berada di kelas. Pelaksanaan simulasi yang pernah dilakukan di MIN 1 Bantul salah satunya simulasi bencama gempa. Prosedur pelaksanaan simulasi bencana gempa meliputi (1) melindungi diri di kolong meja, (2) keluar dengan melindungi kepala menggunakan benda misalnya tas, dan (3) berkumpul di tempat evakuasi. Pada prosedur yang kedua yaitu keluar dengan melindungi kepala menggunakan benda, peserta didik diajarkan untuk tertib, disiplin maupun saling percaya pada temannya.

\section{Kerjasama}

Nilai kerjasama ini muncul ketika pihak MIN 1 Bantul mengadakan kegiatan simulasi bencana. Pada saat kegiatan simulasi dilaksanakan tentunya memerlukan kerja sama baik dari peserta didik, guru, UKS, dan sebagainya. Sikap kerjasama ini tentunya harus terus ditanamkan pada peserta didik guna membentuk karakter peserta didik dengan memberikan pemahaman manusia itu saling membutuhkan dan tolong menolong.

\section{Tolong menolong}

Sikap saling tolong menolong ini ditanamkan sejak dini pada peserta didik. Melalui program sekolah aman bencana ini, peserta didik dilatih untuk menyelamatkan dirinya (menolong dirinya)

06.45 WIB. serta menolong orang lain. Program untuk melatih sikap empati maupun tolong menolong yang sudah dilaksanakan di MIN 1 Bantul berupa dokter kecil dan tim penyelamat korban (satgas). Program tersebut dilaksanakan dengan melibatkan langsung peserta didik MIN 1 Bantul.

Selain itu, berdasarkan hasil observasi terlihat ada salah satu peserta didik sakit kemudian temannya merangkul dan mengantarkan ke UKS kemudian yang lainnya memberikan informasi guru bahwasannya peserta didik tersebut sakit. ${ }^{4}$

\section{Sikap siaga}

Sikap siaga ini muncul ketika peserta didik sudah terbiasa dilatih dalam simulasi bencana. Latihan simulasi bencana ini memiliki tujuan salah satunya agar peseta didik lebih tenang, tidak panik, tidak teriak-teriak serta tetap siaga ketika terjadi bencana. Sikap kesiapsigaan ini perlu ditumbuhkan sejak dini pada peserta didik mengingat bencana dan bahaya dapat terjadi kapan saja, dimana saja. Untuk itu, peserta didik MIN 1 Bantul dilatih simulasi bencana setiap tahun minimal 2 kali.

\section{Religius}

Sikap religius ini telah menjadi bagian dari visi, misi serta tujuan MIN 1 Bantul. MIN 1 Bantul menanamkan sikap religius mengadakan berbagai kegiatan ataupun rutinitas. Misalnya, pembiasaan sebelum belajar berdoa, adanya sholat dhuha, tadarus bersama, serta adanya ziarah ke makam pendahulu MIN 1 Bantul. Beberapa peserta didik menjelaskan hari itu mereka mengikuti ziarah tokoh-tokoh MIN 1 Bantul terdahulu guna memperingati harlah ke-51 MIN 1 Bantul yang akan dilaksanakan pada hari Sabtu, 3 Februari 2018 di halaman MIN 1 Bantul. MIN 1 Bantul sudah melakukan persiapan guna suksenya acara harlah tersebut misalnya, sudah didirikannya tenda dan pemasangan banner guna memeriahkan acara yang akan dilaksanakan. ${ }^{5}$

\footnotetext{
${ }^{4}$ Hasil observasi di MIN 1 Bantul pada hari Senin, 6 Februari 2018 pukul 08.00 WIB.

${ }^{5}$ Hasil observasi di halaman MIN 1 Bantul pada
} 
Tabel 1. Aspek struktural dan non struktural MIN 1 Bantul

\begin{tabular}{|c|c|c|}
\hline \multirow{2}{*}{ Aspek } & \multicolumn{2}{|r|}{ Sekolah Aman Bencana MIN 1 Bantul } \\
\hline & Pilar sekolah aman bencana & Sarana prasarana/kebijakan/program \\
\hline Struktural & $\begin{array}{l}\text { Pilar 1 } \\
\text { Fasilitas sekolah aman }\end{array}$ & $\begin{array}{l}\text { Gedung yang kuat, Tempat Parkir, UKS, Green house, Halaman, } \\
\text { Tangga, Wastafel, Meja Peserta didik, Kursi Peserta didik, Meja } \\
\text { guru, Kursi guru, Rak sepatu, Peta jalur evakuasi, Petunjuk arah } \\
\text { evakuasi, Pemadam kebakaran (APAR), Kotak P3K, Sumber } \\
\text { air bersih, Warning tools (alarm peringatan), Papan visi misi, } \\
\text { Papan bertuliskan "Parkir menghadap keluar!", Papan bertuliskan } \\
\text { "Dilarang merokok!" }\end{array}$ \\
\hline Non struktural & $\begin{array}{l}\text { Pilar } 2 \\
\text { Manajemen kebijakan }\end{array}$ & $\begin{array}{l}\text { Visi misi memuat sekolah aman } \\
\text { Mou dengan PLAN } \\
\text { Mou dengan LINGKAR } \\
\text { Mou dengan FPRB } \\
\text { Mou dengan Puskesmas Pleret } \\
\text { Membentuk komite sekolah } \\
\text { Adanya forum patembayan } \\
\text { Kerjasama dengan ahli psikologi }\end{array}$ \\
\hline Non struktural & $\begin{array}{l}\text { Pilar } 3 \\
\text { PRB }\end{array}$ & $\begin{array}{l}\text { Dokter kecil } \\
\text { Satgas atau tim penyelamat } \\
\text { Simulasi bencana sebanyak } 2 \text { kali setiap setahun } \\
\text { Pembelajaran yang terintegrasi dengan pendidikan pencegahan } \\
\text { risiko bencana } \\
\text { Ekstrakurikuler Pramuka }\end{array}$ \\
\hline
\end{tabular}

Secara keseluruhan melalui program sekolah aman bencana di MIN 1 Bantul mampu dan berhasil menanamkan nilai-nilai karakter pada peserta didik. Selain itu, melalui sekolah aman bencana MIN 1 Bantul mampu membentuk budaya kesiapsiagaan pada peserta didik, guru, karyawan, orang tua dan tamu MIN 1 Bantul. Budaya kesiapsiagaan yang ada di MIN 1 Bantul harus dilakukan secara terus menerus sehingga tidak hilang sebagai ciri khas MIN 1 Bantul.

\section{KESIMPULAN}

Berdasarkan hasil penelitian dapat diambil kesimpulan sebagai berikut:

1. Motivasi MIN 1 Bantul membentuk sekolah aman bencana dilatarbelakangi gempa tahun 2006. MIN 1 Bantul menyadari akan pentingnya pendidikan keamanan bagi warga madrasah. Untuk itu, MIN 1 Bantul mengadakan program sekolah aman bencana.

Jumat, 2 Februari 2018 pukul 09.00 WIB.
2. Model sekolah aman bencana di MIN 1 Bantul berupa sekolah siaga bencana. Program tersebut sudah dilaksanakan secara baik. Program sekolah aman bencana sudah masuk dalam visi misi dan tujuan MIN 1 Bantul. Pelaksanaan program sekolah aman bencana di MIN 1 Bantul sudah sesuai dengan kerangka kerja struktural dan non struktural sekolah aman serta 3 pilar sekolah aman bencana yang meliputi fasilitas sekolah aman, manajemen bencana di sekolah dan pendidikan pencegahan dan pengurangan risiko bencana.

3. Keterkaitan program sekolah aman bencana dalam pendidikan karakter yaitu program sekolah aman bencana MIN 1 Bantul dilaksanakan melalui pembiasaan guna menanamkan nilai karakter yang mencerminkan budaya sekolah aman bencana. Penanaman pendidikan karakter dapat melalui berbagai program madrasah/ sekolah dengan menggunakan beberapa pendekatan atau multi-approach. 
Penanaman nilai-nilai karakter melalui: (a) pendekatan terintegrasi dalam semua mata pelajaran, (b) pengembangan budaya satuan pendidikan, (c) pelaksanaan kegiatan ekstrakurikuler pramuka, dan (d) pembiasaan perilaku dalam kehidupan madrasah. Selain itu melalui pendekatan inkulkasi (inculcation), keteladanan (modeling), fasilitasi (facilitation), dan pengembangan keterampilan (skill building). Nilai karakter yang teraktualisasikan dalam sekolah aman bencana berupa nilai karakter disiplin, tanggung jawab, kerjasama, saling percaya, tolong menolong, sikap siaga, dan religius.

\section{DAFTAR PUSTAKA}

Biro Perencanaan Dan Kerjasama Luar Negeri Sekretariat Jenderal Kemendikbud, Modul 2:Manajemen Bencana di Sekolah, Jakarta: Kementerian Pendidikan dan Kebudayaan bekerjasama dengan UNICEF, 2015.

Biro Perencanaan Dan Kerjasama Luar Negeri Sekretariat Jenderal Kemendikbud, Modul 1:Pilar 1 Fasilitas Sekolah Aman, Jakarta: Kementerian Pendidikan dan Kebudayaan bekerjasama dengan UNICEF, 2015.

Biro Perencanaan Dan Kerjasama Luar Negeri Sekretariat Jenderal Kemendikbud, Modul 1:Pilar 1 Fasilitas Sekolah Aman, Jakarta: Kementerian Pendidikan dan Kebudayaan bekerjasama dengan UNICEF, 2015.

Kementerian Pendidikan dan Kebudayaan Republik Indonesia, Konsep dan Pedoman Penguatan Pendidikan Karakter Tingkat Sekolah Dasar dan Sekolah Menengah Pertama, Jakarta: Kementerian Pendidikan dan Kebudayaan Republik Indonesia, 2017.

Kementerian Pendidikan dan Kebudayaan, Pendidikan Tangguh Bencana: Mewujudkan Satuan Pendidikan Aman Bencana di Indonesia, (Jakarta: Kementerian Pendidikan dan Kebudayaan, 2017
Mardiani, Dewi, "Menteri: Anak Perempuan Rentan Jadi Korban Bencana", Republika,dalamhttp://nasional. republika.co.id/berita/nasional/ umum/13/10/11/mui6hn-menteri-anakperempuan-rentan-jadi-korban-bencana pada 14 Oktober 2017.

Narwanti, Sri, Pendidikan Karakter, Yogyakarta: Familia, 2011.

Nufika,Abdul Haris, "Kunjungan MenteriMenteri Se-Asia ke MIN Jejeran", Kemenag Bantul, dalam www.bantul. kemenag.go.id diakses tanggal 28 Mei 2017.

Obioma, Godswill, "Child Safety Education in Schools: Basis for Community Involvement in Safety Management in Nigeria", Paper dipresentasikan dalam Annual Corps Marshal Conference and the 19th Anniversary Celebration of the Federal Road Safety Commission, Abeokuta, 19-22 February, 2007.

Peraturan Kepala Badan Nasional Penanggulangan Bencana Nomor 04 Tahun 2012 tentang Pedoman Penerapan Sekolah/Madrasah Aman dari Bencana.

Pramesti, Olivia Lewi,“60\% Anak di Dunia Korban Bencana Alam", "National Geographic Indonesia", dalam http://nationalgeographic.co.id/ berita/2012/10/60-anak-di-dunia-korbanbencana-alam diakses tanggal 20 Januari 2017.

Sulistyowati, Endah, Implementasi Kurikulum Pendidikan Karakter, Yogyakarta: Citra Aji Prama, 2012.

Undang-Undang Nomor 23 Tahun 2002 tentang Perlindungan Anak.

UNHCR, Safe Schools and Learning Environment: How to Prevent and Respond to Violence in Refugee Schools, Geneva: Technical Support Section Division of Operational Services UNHCR, 2007. 